Fifth International Conference on Sustainable Construction Materials and

Technologies. http://www.claisse.info/Proceedings.htm

\title{
FORMULATION OF HYDRAULIC CEMENT FROM NIGERIA SEASHELL AND STAPLE CROP HUSK POWDERS
}

\author{
Oyejobi, Damilola ${ }^{1,}$,Raji Sabur $\mathrm{A}^{2}$, Mohammed Jameel ${ }^{3}$ and Alabi Olaitan ${ }^{4}$ \\ ${ }_{1,2,4}$ Department of Civil Engineering, University of Ilorin, Ilorin, Nigeria \\ ${ }^{3}$, Department of Civil Engineering King Khalid University, Saudi Arabia \\ oyejobi.do@unilorin.edu.ng, saraji@unilorin.edu.ng, jameeliitd@gmail.com, \\ olaitanalabi046@gmail.com
}

\begin{abstract}
Cement clinker compounds are basically formed from the reaction between silica and calcium oxides to form C-S-H hydrate. This study blended enormous agricultural waste products of seashells and staple crop husk powders in different mix proportion to form new cement material. The chemical analysis revealed seashells and staple crop powders contained over $80 \%$ calcium and silica oxides respectively. This work further investigated the production of cementitious materials that will conform to Portland cement without any need for chemical activation and heat curing as a practice in alkali-activated cementing material. Some of the physical requirements and chemical composition required for the cement and cement compounds were conducted for this new blended cement material. This is followed up with the determination of optimal strength and fresh properties for cement mortar and paste tests respectively. The benefits of this study include reduction in the green-house gases, re-use of waste products for economic value and better cement properties.
\end{abstract}

Keywords: Cement clinker, waste products, blended cement, heat curing, alkali-activated, optimal strength

\subsection{INTRODUCTION}

Palm Oil Fuel Ash (POFA) is one of the by-products from the palm oil mill industry whose recycling potential is yet to be fully exploited, Okafor and Okonkwo (2009). Palm oil is generally produced in most of the Eastern, Western and Southern parts of Nigeria, a total of about 930 metric ton of palm oil at a growth rate of $2.20 \%$ per annum is produced in Nigeria as reported by Opeyemi and Makinde (2012). Palm oil is consumed in almost all the households in Nigeria on a daily bases leaving behind large amount of residues like fibers, nutshells and empty fruit bunches. Also, rice is a typical example of staple crop with rice husk as a byproduct of the milling process of rice paddy. The normal practice is to dispose large quantities of this rice husk and Palm oil fuel ash without any commercial returns and consequently causing environmental pollution and occupying useful space. As we know that Portland cement has been in existence for decades and due to its production cost, energy consumption, associated problems with emission of green-house gases, and durability issues, there is need for sustainable and alternative for Portland cement. In a study 
of Rice Husk Ash Refractory, Onojah, Agbendeh, and Mbakaan (2013) performed an open air burning of the rice husk, cooled in an open environment for 24 hours and then a Carbolite furnace was used to fire the ashes at a controlled temperature of $650^{\circ} \mathrm{C}$ producing a white amorphous rice husk ash. In Ettu et al. (2013), after air-drying the rice husk, a locally fabricated combustion chamber that is below $650^{\circ} \mathrm{C}$ is used to combust the husk into ashes. (Akogu and Obumneme 2013) \& Abalaka (2013) produced RHA by using a charcoal fired incinerator at a recorded maximum temperature of $838^{\circ} \mathrm{C}$. In Agbenyeku and Aneke (2014), rice husks are sun dried, burnt in open air and calcined in an electric furnace to a temperature of about $700^{\circ} \mathrm{C}$. Oyejobi, Abdulkadir, and Ajibola (2014) carried out partial replacement of cement with rice husk ash by burning rice husk at a controlled temperature of about $700^{\circ} \mathrm{C}$ for a period of four hours. The ash produced are further grounded using mortar and pestle, Oyejobi, Abdulkadir, and Ajibola (2014) and hammer mill in (Akogu and Obumneme 2013). However, in Ettu et al. (2013) while studying the compressive strength of concrete produced by partially replacing cement with RHA, did not mill the ash collected from RHA dump rather uses $600 \mu \mathrm{m}$ sieve and discarded the large particles retained on the sieve.

In the work of Opeyemi and Makinde (2012), the result shows POFA with specific gravity of 2.02 while in Obilade (2014) the specific gravity is in the range of $1.9-2.4$. A study of durability properties of palm oil fuel ash Self Compacting Concrete (SCC) by (Ayininuola and Olaosebikan 2013) concluded that acid resistance and high strength SCC can be produced from the combination of palm oil fuel ash and conplast SP432MS (superplastisizer). Olivia and Oktaviani (2017) partially replaced cement at $4 \%$ with cockle and marsh clams. It was reported that mechanical properties of cockle clam are lower than the control mix of OPC while marsh clam yielded increased mechanical properties. The differences were attributed to different Calcium oxides in each of the clam. Lertwattanaruk, Makul, and Siripattarapravat (2012) utilized four types of clams with a cement replacement ranging between 5 to $20 \%$ by weight. It was discovered that there is a result of adequate strength, water requirement and increased in setting times of the mortars, although increase in the percentage of clam shells reduced the compressive strength due to the less reactivity. Umoh and Olusola (2013) studied performance of Portland-pozzolan cement in acidic medium with a mixture of OPC and Periwinkle shell ash with a ratio between 10 to $40 \%$ by volume. Increase in the percentage of periwinkle shell ash increases water requirement. Compressive strength increases with casting age but decreases with percentage increase in periwinkle shell ash due to the higher water content. Loss in compressive strength in $\mathrm{MgSO}_{4}$ solution was reduced for Portland-pozzolan compared to percentage in the OPC mix. Barbachi et al. (2017) characterized crushed mussel shells for their possibility use in the concrete. Muthusamy and Sabri (2012) replaced coarse aggregates with cockle shell up to 30\%, however, $20 \%$ replacement gave best workability and compressive strength results. Rough shape of the shell has attributed to the low workability but also improved bonding and hence compressive strength of the concrete. Ponnada, Prasad, and Dharmala (2016) substituted both fine and coarse aggregates with granite powder and cockle shells with the maximum compressive strength of $43.7 \mathrm{MPa}$ for $20 \%$ and $15 \%$ of granite powder and cockle shells. Othman et al. (2013) used cockle shell ash to replace cement between the amount of 5 to $50 \%$ with the decrease in compressive as the percentage increases. High content of Calcium oxide causes slow hydration process. Importantly, permeability and porosity of the concrete with cockle shell ash reduced compared to the control mix. In our study, hydraulic cement is formulated from the waste products that are cementititous materials and the necessary tests are conducted on the suitability of this material in full replacement of cement. 


\subsection{MATERIALS AND METHODS}

The following materials are used in this study for the production of hydraulic cement with their sketches in Figure 1. These include clam shells, Palm oil fuel ash and rice husk ash. These materials in their raw form are available in large quantities in Nigeria.
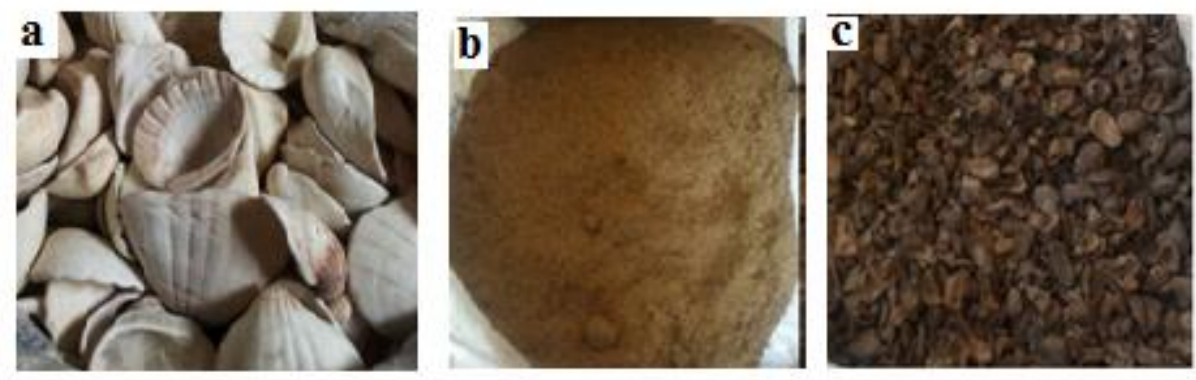

Figure 1: (a) Clamshells (b)Rice Husk and (c) Palm Oil Fuel Shells in their raw form

After sourcing for these materials, they were all pre-treated through washing with detergent and clean, water and then grounded to the powdery form individually as shown in Figure 2.

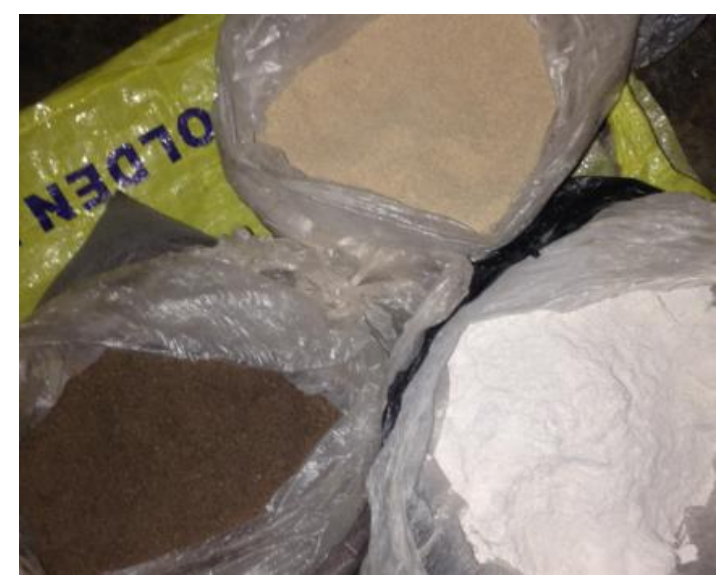

Figure 2: Grounded powders of Clamshells, Rice Husk and Palm Oil Fuel Shells

In order to eliminate the Carbon dioxide in the materials and to allow for the chemical reaction to take place, the materials are proportioned together following the Table 1.

Table 1: Different proportions for the hydraulic cement formulation

\begin{tabular}{cccc}
\hline & Clam (kg) & POFA (kg) & RHA (kg) \\
\hline Mix 1 & 0.84 & 0.10 & 0.07 \\
Mix 2 & 0.53 & 0.16 & 0.11 \\
Mix 3 & 0.45 & 0.09 & 0.09 \\
\hline
\end{tabular}

The rationale behind these mixes was followed from the Scrivener (2003) where $80 \%$ of the limestone and $20 \%$ of shale were used as raw materials in the production of cement kiln. In our 
case, the clamshell materials were initially incinerated at a temperature of $700{ }^{0} \mathrm{C}$ for three hours for decarbonation to take place and this temperature is increased to $1200^{\circ} \mathrm{C}$ and grounded powders of rice husk and palm oil fuel shell were added and allowed to stay for another four hours for the chemical reaction and formulation of Calcium Silicate minerals. The furnace used for the incineration was shown in Figure 3. The cement clinker was further taken to grinder and this is grounded to finer particles.

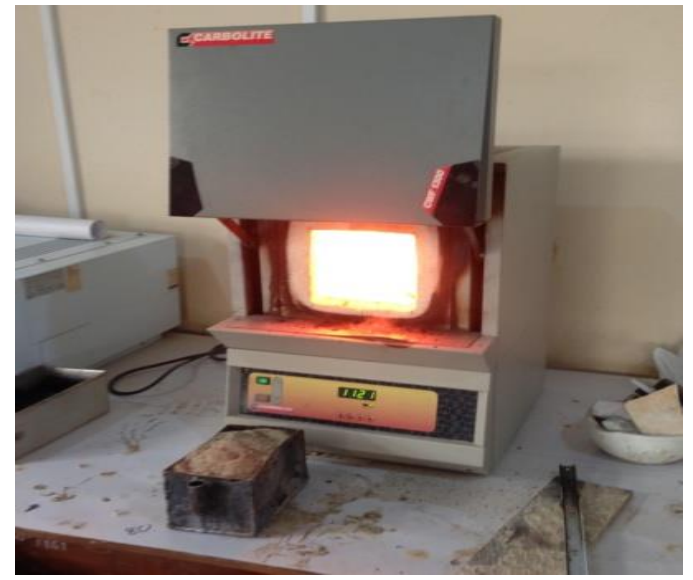

Figure 3: Incineration of materials inside the furnace

\subsection{RESULTS AND DISCUSSION}

The clinker was tested for the following physical properties which include fineness, specific gravity and specific surface area. The particle size distribution for the three mixes was shown in Figure 4 with $80.26 \%, 81.64$ and $87.14 \%$ passing 45 micrometer sieve size respectively. The specific surface area for the mixes were $5.18,4.76$ and $5.86 \mathrm{~m}^{2} / \mathrm{g}$ respectively. Again, specific gravity of the hydraulic cement was slightly lower than the Portland cement with the values of $2.95,2.93$ and 2.98 respectively. The individual chemical compositions of the raw materials and that of the blended cement were shown in Table 2.

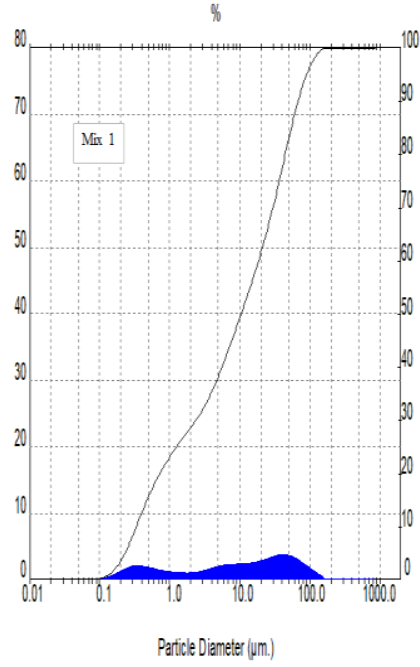

Paricle Diameter (um.)

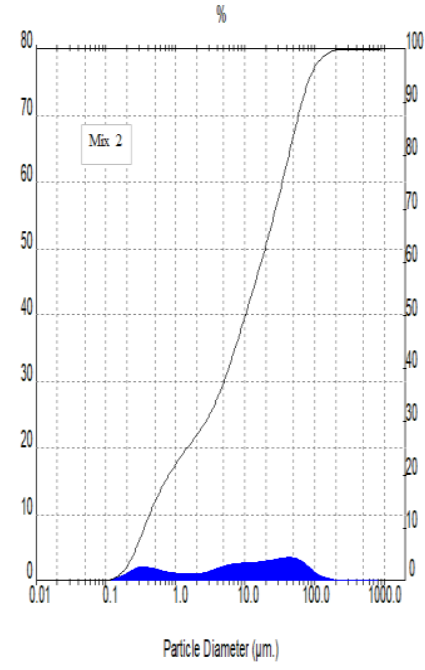

Paricle Diameter (um.)

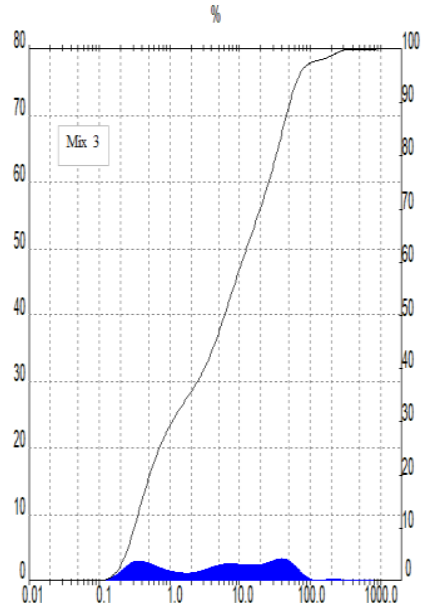

Paricle Diameter (um.) 
Figure 4: Particle size distributions of the cement clinker

Table 2: Chemical composition of the raw and finished cement materials

\begin{tabular}{ccccc}
\hline Material & Clam (\%) & POFA (\%) & RHA (\%) & Hydraulic cement of Mix 3 (\%) \\
\hline $\mathrm{SiO}_{2}$ & 0.27 & 53.52 & 77.23 & 23.23 \\
$\mathrm{Al}_{2} \mathrm{O}_{3}$ & 0.06 & 11.40 & 3.59 & 4.59 \\
$\mathrm{CaO}$ & 97.46 & 4.62 & 8.95 & 49.90 \\
$\mathrm{Fe}_{2} \mathrm{O}_{3}$ & 0.22 & 12.68 & 9.85 & 3.42 \\
$\mathrm{Na}_{2} \mathrm{O}$ & 0.98 & 1.56 & 2.90 & 1.05 \\
$\mathrm{MgO}$ & 0.09 & 3.28 & 5.85 & 2.62 \\
$\mathrm{~K} 2$ & 0.38 & 3.08 & 4.08 & 1.05 \\
$\mathrm{LOI}$ & 43 & 4.83 & 4.84 & 3.65 \\
\hline
\end{tabular}

Following this chemical analysis, a paste was formed from the hydraulic cement and the initial and final setting times, consistency and flow values are determined following ASTMC191 (2008). The water requirement according to ASTMC109 (2015) was carried out and due to the higher value of specific surface area, the water demand was higher than the stated values and a value of 0.38 water-cement ratio was used in order to have a flowable paste as recorded in the Table 3 . The initial and final setting times of the mixes were relatively close to each other with the average initial and final setting times of 68 and 137 minutes respectively.

Table 3: Fresh properties of the cement paste

\begin{tabular}{cccc}
\hline & Mix 1 & Mix 2 & Mix 3 \\
\hline Initial setting time (Mins) & 70 & 65 & 70 \\
Final setting time (Mins) & 130 & 140 & 140 \\
Flow (mm) & 130 & 135 & 132 \\
\hline
\end{tabular}

On the final note, compressive strength of the mortar (1:2.75, cement to sand) ratio shown in Table 4 made from the hydraulic cement and 20\% Portland cement was tested at ages of 3, 7, 14 and 28 days respectively with the results shown in Table 5 and Figure 4 respectively. The compressive strength values of the mortar at 28th day were slightly lower than the strength made from 100\% Portland cement mortar in Lertwattanaruk, Makul, and Siripattarapravat (2012) which recorded value of $15 \mathrm{MPa}$, although the strength increases with the increase in the curing age. This can be attributed to the trial combinations of the raw materials as well as the higher water cement ratio which increases the flow and reduces the compressive strength in the turn.

Table 4: Mortar mix of ratio 1: 2.75

\begin{tabular}{ccc}
\hline Cube $($ No) & Cement $(\mathrm{g})$ & Fine Aggregate $(\mathrm{g})$ \\
\hline 12 & 1000 & 2750 \\
\hline
\end{tabular}

Table 5: Compressive strength of hydraulic cement mortar

$\begin{array}{llll}\text { Compressive Strength (MPa) } & \text { Mix } 1 & \text { Mix } 2 & \text { Mix } 3\end{array}$




\begin{tabular}{cccc}
\hline 3 days & 3.20 & 3.50 & 3.60 \\
7 days & 5.00 & 6.20 & 5.80 \\
14 days & 8.40 & 9.30 & 9.00 \\
28 days & 10.50 & 12.40 & 11.80 \\
\hline
\end{tabular}

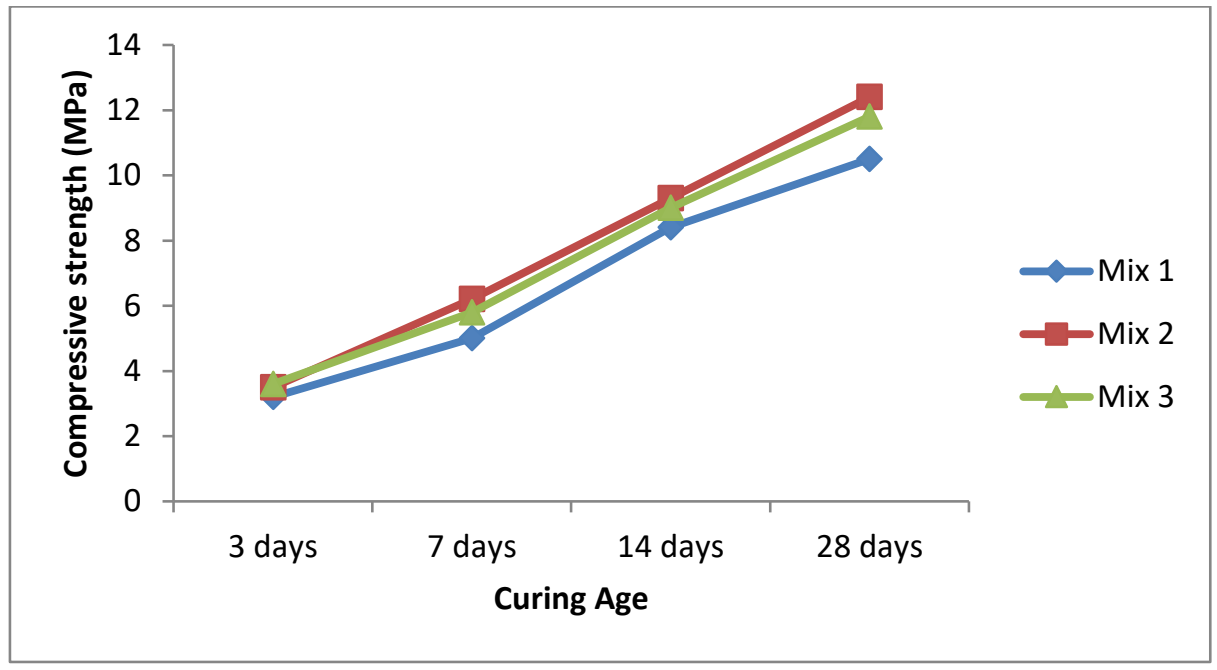

Figure 4: Compressive strength of hydraulic cement mortar at different curing ages

\subsection{CONCLUSION}

From the above, it could be concluded from the preliminary study that the performance study of the new cement material formulated from the waste products are possible and in addition possess comparable physical, chemical and mechanical properties similar to the Portland based mortar cement. Most of the tests are within the standard range set out for Portland cement and therefore this new cement material if commercialized on a large scale after satisfactory necessary tests can replace Portland cement and enormously reduce waste products for economic value.

\section{ACKNOWLEDGMENT}

The first author would like to extend his appreciation to Tertiary Education Trust Fund for sponsoring his conference attendance which was facilitated through the Centre for International Education, University of Ilorin, Nigeria.

\subsection{REFERENCES}

Abalaka, Elijah. 2013. "Influence of water-binder ratio on normal strength concrete with rice husk ash." International Journal of Sciences no. 2 (2013-02):28-36. 
Agbenyeku, EE, and IF Aneke. 2014. "Blended Rice Husk Ash Concrete; A Marginal Green Construction Material from Extended Hydration International Journal of Scientific and Engineering Research."

Akogu, E O, and G O Obumneme. 2013. "Strength Development and Durability Prperties of Concrete containing Pre-soaked Rice Husk Ash."

ASTMC109. 2015. Standard Test Method for Compressive Strength of Hydraulic Cement Mortars (Using 2-in. or [50-mm] Cube Specimens), ASTM International, West Conshohocken, PA. ASTMC191. 2008. "Standard Test Methods for Time of Setting of Hydraulic Cement by Vicat Needle" ASTM Annual Book of ASTM Standards.

Ayininuola, Gbenga M, and Oluwatobi I Olaosebikan. 2013. "Influence of Rice husk ash on soil permeability." Transnational Journal of Science and Technology no. 3 (10):29-33.

Barbachi, Mohamed, Abdellatif Imad, Faouaz Jeffali, Khaled Boudjellal, and Mohamed Bouabaz. 2017. "Physical characterization of sea shell for a concrete formulation."

Ettu, LO, CA Ajoku, KC Nwachukwu, CTG Awodiji, and UG Eziefula. 2013. "Strength variation of OPC-rice husk ash composites with percentage rice husk ash." International Journal of Applied Science and Engineering Research no. 2 (4):420-424.

Lertwattanaruk, Pusit, Natt Makul, and Chalothorn Siripattarapravat. 2012. "Utilization of ground waste seashells in cement mortars for masonry and plastering." Journal of environmental management no. 111:133-141.

Muthusamy, K, and NA Sabri. 2012. "Cockle shell: a potential partial coarse aggregate replacement in concrete." International Journal of Science, Environment and Technology no. $1(4): 260-267$.

Obilade, IO. 2014. "Experimental study on rice husk as fine aggregates in concrete." Int J Eng Sci no. $3(8): 9-14$.

Okafor, Fidelis O, and Ugochukwu N Okonkwo. 2009. "Effects of rice husk ash on some geotechnical properties of lateritic soil." Nigerian Journal of Technology no. 28 (1):46-52.

Olivia, Monita, and Revina Oktaviani. 2017. "Properties of Concrete Containing Ground Waste Cockle and Clam Seashells." Procedia engineering no. 171:658-663.

Onojah, AD, NA Agbendeh, and C Mbakaan. 2013. "Rice husk ash refractory: the temperature dependent crystalline phase aspects." Ijrras no. 15 (2):246-248.

Opeyemi, DA, and OO Makinde. 2012. "The suitability of partial replacement of cement with rice husk ash and bone powder in concrete structures." International journal of emerging technology and advanced engineering no. 2 (9):261-265.

Othman, Nor Hazurina, Badorul Hisham Abu Bakar, MM Don, and MAM Johari. 2013. "Cockle shell ash replacement for cement and filler in concrete." Malaysian Journal of Civil Engineering no. 25:201-211.

Oyejobi, Damilola Oyewumi, Taofeeq Sholagberu Abdulkadir, and Victor Motolani Ajibola. 2014. "Investigation of rice husk ash cementitious constituent in concrete." International Journal of Agricultural Technology no. 10 (3):533-542.

Ponnada, Markandeya Raju, S Siva Prasad, and Harish Dharmala. 2016. "Compressive strength of concrete with partial replacement of aggregates with granite powder and cockle shell." Mal. J. Civ. Eng no. 28 (2):183-204.

Scrivener, KL. 2003. Advanced concrete technology: constituent materials. Oxford: Elsevier.

Umoh, AA, and KO Olusola. 2013. "Performance of periwinkle shell ash blended cement concrete exposed to magnesium sulphate." Civil Engineering Dimension no. 15 (2):96-101. 